\title{
The Inevitable Reforms of the Legislative Competencies of the East African Legislative Assembly
}

\author{
By Kennedy Gastorn*
}

\begin{abstract}
This article examines the ongoing tension on the power to initiate bills between the East African Legislative Assembly (EALA) as a legislative organ of the East African Community (the EAC) and the EAC Council of ministers (the Council) as a policy organ of the EAC. It argues that the current tension can only be addressed through amending the Treaty for the Establishment of the East African Community of 1999 (the Treaty) and realigning the legislative processes by subjecting private members' bills to the Council's approval, which must not unreasonably be withheld. Any arbitrary denial of approval by the Council should be subjected to a judicial review by the East African Court of Justice. Currently, the Treaty gives both the EALA and the Council powers to initiate bills for the EAC legislation. The tension between these two organs of the EAC is primarily reflected by EALA initiating bills on matters under negotiation or already opposed or agreed upon by the Council, hence reopening the concluded negotiations. Using experiences from other regional parliamentary bodies such as the European Parliament, this paper discusses the mandate and relevance of the EALA and the Council in relation to the law making processes in the EAC. It also reviews the ongoing efforts of the partner states to address this tension through an amendment to the Treaty. Additionally, it analyses the relevance of the doctrine of the separation of powers to the regional integration schemes and recommends a coordination scheme for a cordial and effective working relationship between the Council and the EALA for the attainment of a prosperous, competitive, secure, stable and politically united EAC.
\end{abstract}

$$
* * *
$$

\section{Introduction}

The East African Legislative Assembly (EALA) is one of six core organs of the East African Community (EAC or Community) established in 1999 under the Treaty for the Establishment of the East African Community (the Treaty). ${ }^{1}$ Other organs include: the Summit of Heads of State, the Council of Ministers and Sectoral Councils, the Coordination Committee and Sectoral Committees, the East African Court of Justice and the Secretariat.

* Associate Professor, Department of Public Law, University of Dar es Salam School of Law. Email: kennedy@udsm.ac.tz.

1 Article 9 of the Treaty. 
The EAC is comprised of five partner states: the Republics of Burundi, Kenya, Rwanda, Uganda and United Republic of Tanzania. The EALA was inaugurated on 30 November 2001 as the legislative organ of the EAC, ${ }^{2}$ barely a year after the coming into force of the Treaty in 2000. To be specific, the EALA, as a parliamentary organ of the EAC, enjoys limited inherent parliamentary powers such as advisory, investigative or supervisory, budgetary oversight and law making powers. ${ }^{3}$ More importantly, as an organ of the EAC, the EALA has been created by the Treaty to promote the achievements of the objectives of the EAC of widening and deepening cooperation among the partner states in political, economic, social and cultural fields, research and technology, defence, security and legal and judicial affairs for their mutual benefit. ${ }^{4}$ The EALA as a regional parliamentary body of a state-centric, intergovernmental organization, namely the EAC, has none of the usual powers of the national parliaments of sovereign states. However, thus far the EALA is the only regional parliamentary body in the world with the power to initiate legislation through its committees or private members' bills. ${ }^{5}$ The European Parliament is the regional parliamentary body that comes closest to the EALA as it performs a legislative function, yet it does not have the power to initiate bills or legislation. ${ }^{6}$

This paper makes a case for more coordination of the EALA mandate to initiate legislation as a shared competency with the EAC Council of Minsters (Council). ${ }^{7}$ Lack of coordination between the EALA and the Council on this shared competency has created an emerging risk of populism in EAC matters, a duplication of efforts and tension among the partner states endangering, if remaining unchecked, the smooth attainment of a prosperous, competitive, secure, stable and politically united EAC. The EALA is increasingly passing bills on matters under negotiation or already opposed or agreed upon by the council, hence reopening the concluded negotiations. At times, the EALA has passed bills on matters outside the scope of the Treaty. It is submitted that lack of cordial and effective working relationship between the Council and the EALA will inevitably hinder performances of the two organs. In April 2012, the United Republic of Tanzania recommended, in vain, the revision of the legislative processes of the EAC partly in addressing this concern. ${ }^{8}$ This paper recommends a harmonious way to handle the said concerns from a broad-based practice of

2 Article 49(1) of the Treaty.

3 Juma Volter Mwapachu, Ten Years of the East African Community - Achievements, Challenges and Prospects, in: Kennedy Gastorn, Harald Sippel, Ulrike Wanitzek (eds.), Processes of Legal Integration in the East African Community, Dar es Salaam 2011, p. 60.

4 Article 5(1) of the Treaty.

5 Article 59 of the Treaty and Rule 64 of the East African Legislative Assembly Rules of Procedure.

6 Roger J. Goebel, Supranational? Federal? Intergovernmental? The Governmental Structure of the European Union After the Treaty of Lisbon, Columbia Journal of European Law 20 (2013), p. 91.

7 Article 14(3)(b) of the Treaty and Article 59 of the Treaty and Rule 64 of the East African Legislative Assembly Rules of Procedure.

8 Report of the Meeting of the High Level Task Force on the Amendment of the Treaty, Kigali, Rwanda, 24 October 2012, para 3.1.2, pp. 6-7. 
other similar regional parliamentary bodies so as to empower the EALA to actively advance the regional integration agenda of the EAC. This is crucial because the EALA is given an independence to exercise its mandate without being bound by any instructions or orders from any person or authority. ${ }^{9}$ At the same time, the Council is the policy organ of the EAC, which is charged also with power to oversee the proper and harmonious functioning and development of the EAC. ${ }^{10}$ In the EAC set-up, the minister responsible for the EAC affairs, chosen by each partner state, who sits in the Council, represents the interests of the partner states. Both Council and EALA members are not popularly elected.

\section{The East African Legislative Assembly (EALA)}

The EALA is the legislative organ of the EAC, comprised of 45 members elected by national parliaments or assemblies and 7 ex-official members. Article 50(1) of the Treaty requires the national assembly of each partner state to elect, not from among its members, nine members representing as much as feasible the various political parties represented in parliament, shades of opinion, gender and special interest groups in that partner state, and in accordance with such procedure as each national assembly may determine. ${ }^{11}$ A person is qualified to be elected a member of EALA if he or she is a citizen of that partner state, qualified to be elected as a member of the national assembly of that partner state, not currently holding office as a minister in that partner state and or an officer in the service of the EAC, and has proven experience or interest in consolidating and furthering the aims and objectives of the EAC. ${ }^{12}$ Once elected, members of the EALA hold office for a five-year term and are eligible for re-election for an additional five years. ${ }^{13}$

The ex-officio members of the EALA include the Minister responsible for EAC affairs from each partner state, the assistant or deputy Minister or Minister of State responsible for EAC affairs from each partner state, the Secretary General of the EAC and the Counsel to the Community. The assistant or deputy Minister or Minister of State responsible for EAC affairs from each partner state participate in the meetings of EALA in case the substantive Minister responsible for EAC affairs from the particular partner state is not present. ${ }^{14}$ All

9 Rule 3(1) of the Rules of Procedures of the East African Legislative Assembly.

10 Article 14 of the Treaty.

11 For cases involving violations of these rules by the partner states see: Prof. Peter Anyang' Nyong'o and 10 Others $v$ Attorney General of Kenya and 5 Others, EACJ Reference No. 1 of 2006 (Kenya was found liable for violating Article 50(1) of the Treaty in electing EALA members by infringing the requirements representation of gender and other special interests), and Anthony Calist Komu v Attorney General of the United Republic of Tanzania, EACJ Reference No. 7 of 2012 (Tanzania was held responsible for violating Article 50(1) of the Treaty by not electing candidates in the category of official opposition party. It had elected EALA members on the categories of Women, Zanzibar, Opposition Parties and mainland Tanzania).

12 Article 50(2) of the Treaty.

13 Article 51(1) of the Treaty.

14 Article 48(1) of the Treaty. 
ex-officio members have no security of tenure or term-limit as they attend the assembly by virtue of their official capacities.

Members of EALA are paid their salaries and allowances by the EAC. This is different from the European Union where parliamentarians are not only elected by popular vote in their home countries, they are also paid by their home countries, despite the huge salary and staffing disparities among them serving in the same job. ${ }^{15}$ Furthermore, EALA members sit as a single chamber, without being divided into a government and opposition, or according to their political affiliation.

Article 49 of the Treaty provides the functions of the EALA. Apart from being the legislative organ of the community, the EALA has also powers to: (a) liaise with the National Assemblies of the Partner States on matters relating to the Community; (b) debate and approve the budget of the Community; (c) consider annual reports on the activities of the Community, annual audit reports of the Audit Commission and any other reports referred to it by the Council; (d) discuss all matters pertaining to the Community and make recommendations to the Council as it may deem necessary for the implementation of the Treaty; (e) recommend to the Council the appointment of the Clerk and other officers of the Assembly; (f) make its rules of procedure and those of its committees, and (g) establish any committee or committees for such purposes as it deems necessary for purposes of carrying out its functions. The EALA may also perform any other functions as are conferred upon it by the Treaty.

It is in this context that the EALA as a parliamentary organ of the EAC gets its parliamentary advisory, investigative or supervisory, budgetary oversight and law making powers. Although the EALA may require the Council to submit any appropriate proposals on matters on which it considers that action is required, the Council is not obliged to pay attention or comply with such requests. ${ }^{16}$ Likewise, the EALA may pose parliamentary questions to the executives but it has limited powers to investigate and hold executives accountable. The EALA cannot subpoena and its questions to the executives automatically lapse if not answered within six weeks. ${ }^{17}$ In other words, the EALA has no power to enforce its decisions. $^{18}$

15 Troy A. Eid, The European Union: A Brief Introduction, The Colorado Lawyer 31 (2002), p. 15.

16 Article 59(3)(b) of the Treaty.

17 Barney Karuuombe, The Role of Parliament in Regional Integration - the Missing Link, in: Anton Bösl, Willi Breytenbach, Trudi Hartzenberg, Colin McCarthy, Klaus Schade (eds.), Monitoring Regional Integration in Southern Africa Yearbook 2008, Stellenbosch 2008, p. 248.

18 Ulf Terlinden, African Regional Parliaments/ Parliamentary Bodies as Engines of Integration: Current State and Challenges, Roundtable on the "Interface between Regional Parliamentary Bodies and the Pan-African Parliament", SADC Parliamentary Forum/Friedrich Ebert Stiftung Namibia (Lusaka, Zambia, 8-9 August 2005), pp. 3-4. 


\section{The EAC Council of Ministers}

The Council consists of the Minister responsible for East African Community affairs of each Partner State, such other Minister of the Partner States as each Partner State may determine and the Attorney General of each Partner State. ${ }^{19}$

The Council is a policy organ of the Community with vast powers to (a) make policy decisions for the efficient and harmonious functioning and development of the Community; (b) initiate and submit Bills to the EALA; (c) give directions to the Partner States and to all other organs and institutions of the Community other than the Summit, Court and the EALA; (d) make regulations, issue directives, take decisions, make recommendations and give opinions in accordance with the provisions of the Treaty; (e) consider the budget of the Community; (f) consider measures to be taken by Partner States in order to promote the attainment of the objectives of the Community; (g) make staff rules and regulations and financial rules and regulations of the Community; (h) submit annual progress reports to the Summit and prepare the agenda for the meetings of the Summit; (i) establish from among its members, Sectoral Councils to deal with such matters that arise under the Treaty as the Council may delegate or assign to them and whose the decisions shall be deemed to be decisions of the Council; (j) establish the Sectoral Committees; (k) implement the decisions and directives of the Summit as may be addressed to it; (l) endeavour to resolve matters that may be referred to it; and $(\mathrm{m})$ exercise such other powers and perform such other functions as are vested in or conferred on it by the Treaty. ${ }^{20}$

The regulations, directives and decisions of the Council made in pursuance of the provisions of the Treaty are binding on the Partner States and on all organs and institutions of the Community except the Summit, the Court and the EALA within their jurisdictions. ${ }^{21}$

The EAC is not a sovereign state. It is an intergovernmental organization that is statecentric. It therefore has no separate interest from those of the partner states as mediated by the Treaty and is hence devoid of predictive and inherent powers. As a state-centric intergovernmental organization, the EAC is a product of strategies pursued by national governments acting on the basis of their preferences and power. ${ }^{22}$ National politics influence and determine the policies pursued by the EAC in the context of the Treaty. For instance, through the Minister responsible for EAC affairs from each partner state in the Council as a policy organ, the EAC seeks and receives instructions and guidance from partner states due to the fear of veto powers that each head of state has in the Summit as the apex organ of the EAC as well as the rule of consensus on all decisions of the Council and the Summit. ${ }^{23}$

19 Article 13 of the Treaty.

20 Article 14 of the Treaty.

21 Article 16 of the Treaty.

22 Jeeyong Kim, Security Externalities, Institutional Veto-Points, and Regional Integration 1945 2004, Buffalo 2011, p. 12.

23 Articles 12(3) and 15(4) of the Treaty. Also see the Protocol on Decision Making by the Council of the East African Community. 
Because of the rule of consensuses, the functions and the survival of the EAC depends on the goodwill of the partner states and the harmonious working relationship between the organs and institutions of the community. ${ }^{24}$ It is only in the EALA that decisions are determined by a majority of the votes of the members present and voting. ${ }^{25}$ However, even here, any head of state may choose not to assent to any Bill to become law. ${ }^{26}$ The EAC is therefore not a supranational body and it represents the interests of the member states, as its constituency, and not the citizens. This means that the citizens' interests are represented by partner states and it is no wonder that all officials and decision makers of the EAC, including the EALA members, are not elected by direct popular vote. The EAC being a body corporate,${ }^{27}$ partner states are the sole shareholders and the governments of partner states are trustees on behalf of their citizens as beneficiaries. Operationally, the EAC is required to operate as a people-centered and market driven enterprise. ${ }^{28}$ The EALA is 'set up to enhance a people centered cooperation'. ${ }^{29}$ This is the context in which the EAC currently operates and must be viewed.

\section{Legislative Powers of the EALA}

The EALA is the only regional parliament in Africa with a legislative mandate. Other similar regional parliaments have more advisory powers including the Economic Community Of West African States (ECOWAS) -Parliament (ECOWAS-P), the Inter-Parliamentary Union of IGAD Member States (IPU-IGAD), the Network of Parliamentarians of the Economic Community of Central African States (REPAC) (Réseau des Parlementaires de la CEEAC), the Pan-African Parliament (PAP), the Parliament of the Union Economique et Monétaire Ouest Africaine (UEMOA) (P-UEMOA), and the Southern African Development Community's Parliamentary Forum (SADC-PF). ${ }^{30}$

Bills under EALA are initiated either by the Council sending a motion to the house ${ }^{31}$ or through private bills by individual members or the committee of the house. Article 59(1) of the Treaty allows any member of EALA to propose any motion or introduce any bill in the house. Rule 64 of the East African Legislative Assembly Rules of Procedure of 2001 adds that every committee of the house, within its area of competence, and every member of EALA has a right to move a private members' bill. It is common knowledge that from its

24 Calist Andrew Mwatela, Lydia Wanyoto Mutende, Isaac Abraham Sepetu v. East African Community, Application No. 1 of 2005, EACJ.

25 Article $58(1)$ of the Treaty.

26 Article 63 of the Treaty.

27 Article 4(1) of the Treaty.

28 Article 7(1)(a) of the Treaty.

29 Calist Andrew Mwatela, Lydia Wanyoto Mutende, Isaac Abraham Sepetu v. East African Community, Application No. 1 of 2005, EACJ, p. 20.

30 Terlinden, note 18 , p. 4.

31 Article 14(3)(b) of the Treaty. 
existence to date, EALA has passed 47 legislations, the majority of which originated from private members' bills. As mentioned above, EALA is the only regional parliamentary body in the world with powers to initiate its legislation through its committees or private members' bills.

The power of the EALA to initiate private members' bills is not without limitations. Article 59(1) bars any motion that does not relate to the functions of the community, any bill that does not relate to a matter to which acts of the community may be enacted. These limitations apply also to the Council. ${ }^{32}$ Moreover, the presiding person or the speaker of the house has a duty to prevent any private members' bills which, in his or her opinion, make provisions (a) for the imposition of any charge upon any fund of the Community, (b) for the payment, issue or withdrawal from any fund of the Community of any moneys not charged thereon or the increase in the amount of any such payment, issue or withdrawal, (c) for the remission of any debt due to the Community and (d) on any motion, including any amendment to a motion, the effect of which, would be to make provision for any of the above purposes. $^{33}$

The biggest challenge with the above limitations is the fact that the onus lies with the opinion of the presiding person. In other words, everything is allowed in the house except those, which the presiding officer may not like, in his/her absolute opinion as violating the set limitations. No wonder the majority of bills passed by EALA originate from private members' bills. The other equally important reason as to why the majority of substantive laws originate from private members' bills is the fact that the Council does not introduce bills. The procedure for a bill to be introduced by the Council is somewhat tedious and complicated because it involves negotiations among the partner states and several approvals. Most bills are negotiated by the relevant Sectoral Councils, then they have to be adopted by the Council, thereafter they are referred to the Sectoral Council on Legal and Judicial Affairs (SCLJA) for legal input. Upon being cleared by the SCLJA they are refered back to the Council and only then introduced to parliament.

Once the house duly passes a bill, the Speaker of the Assembly is required to directly submit the said bill to the Heads of State for assent. The Heads of State may assent or withhold assent or return the bill not assented back to the house with reasons within 90 days from the date on which it was passed. The house is required to reconsider the bill and resubmit the same to the Heads of State for assent. The bill automatically lapses if a head of state withholds assent to re-submit the bill. ${ }^{34}$

Laws enacted by EALA are directly enforceable and take precedence on all laws of partner states on similar matters pertaining to the implementation of the Treaty, except the

32 Calist Andrew Mwatela, Lydia Wanyoto Mutende, Isaac Abraham Sepetu v. East African Community, Application No. 1 of 2005, EACJ.

33 Article 59(2)(a) and (b) of the Treaty.

34 Article 63 of the Treaty. 
national Constitutions. ${ }^{35}$ Within the hierarchy of community laws, EALA laws cannot simply override the protocols and the Treaty, because protocols are an integral part of the Treaty. ${ }^{36}$ EALA laws are of the same value as regulations, directives and decisions of the Council as both constitute secondary law to, and operationalizing, the Treaty (primary law). It is therefore necessary to avoid any conflict that may arise between legislation enacted by EALA and regulations and directives emanating from the Council.

The Minister responsible for East African Community affairs of each Partner State, like all other ex-officio members, does not participate fully in the legislative process. They sit in the EALA but have no voting right. ${ }^{37}$ Also, sectoral ministers are not allowed in the house even when the house is debating bills regulating their sectors. Voting in the EALA is not conducted along proportionally weighed representation, as it is the case in the legislative process of the European Parliament where each member state is assigned votes based roughly on its population. ${ }^{38}$

\section{The European Union Legislative Process}

The European Union is a good model from which the EAC might learn various lessons, not because the European Union is any closer to a perfect union, as it has its own fair problems or challenges, including democratic deficits in various aspects ${ }^{39}$, but because its parliament is the only comparable regional parliament with a legislative function like the EALA. It is also common knowledge that the existing influence, involvement and support of the European Union and its member states of the EAC integration project makes the EU a natural fallback comparative position for the EAC.

The European Parliament is constituted by members elected by direct universal suffrage. Slots are allocated to the member states according to the principle of degressive proportionality with a minimum seats allocated to Malta and a maximum seats allocated to Germany. ${ }^{40}$ While the parliament is not divided into a government and opposition, members do sit according to their multinational groups of political affiliation. A political group is constituted by at least 25 members representing at least $25 \%$ of existing member states. The political groups include the European People's Party (Christian Democratics), the Progressive Alliance of Socialists and Democratics in the European Parliament, the Alliance of Liberals and Democrats for Europe, the European Conservatives and Reformists, the

35 Article 8(4) of the Treaty.

36 Article 151(4) of the Treaty.

37 Article 58(2) of the Treaty.

38 Eid, note 15, p. 15; Duncan E. Alford, European Union Legal Materials: A Guide for Infrequent Users, Law Library Journal 97 (2005), p. 61.

39 Ralph H. Folsom, Principles of European Union Law, Minnessota 2014, p. 25.

40 Alina Kaczorowska-Ireland, European Union Law, Hoboken 2013, p. 84. 
Greens or European Free Alliance, the Confederal Group of the European United LeftNordic Green Left, and the Europe of Freedom and Democracy Group. ${ }^{41}$

In the European Union, five institutions are involved in the legislative process, namely (a) the European Commission, (b) the Council of the European Union, (c) the European Parliament, (d) the Committee of the Regions, and (e) the Economic and Social Committee. According to Duncan Alford, the European Commission, the council of the European Union and the parliament are primarily involved in enacting legislation, while the Economic and Social Committee and the Committee of the Regions both serve in a consultative role. ${ }^{42}$ The European Commission is comprised of one commissioner chosen by each member state and is vested with sole power to initiate bills and monitor the evolution of the bill throughout the Council of the European Union and the European Parliament. Article 17(3) of the Treaty on European Union of 2010 says that members to the European Commission must be chosen on the ground of their general competence and European commitment from persons whose independence is beyond doubt. The European Parliament has no mandate to directly propose any legislation but may request the European Commission to propose a particular legislation. The Council of Ministers or one million citizens who are nationals of a significant number of Member States may also invite the European Commission to submit a proposal for legislation. ${ }^{43}$ This is in line with the simplified European Union governance process where "the European Commission proposes, the Parliament advises, the Council of the European Union decides, and the Court of Justice rules". ${ }^{44}$ This makes the relationship of the Parliament and the Council of the European Union as a federal style bicameral legislative. $^{45}$

According to Article 17(3) of the Treaty on European Union 2010, the European Commission is under no obligation to further the interest of specific countries, and must be completely independent in the performance of its duties for the sole interest of the European Union. ${ }^{46}$ It has been observed that the sole power to initiate all legislation was vested in the European Commission deliberately to ensure that legislative drafts are formulated by the European Union institution obliged to act independently and without regard to any specific national interests for the general interest of the Union. ${ }^{47}$ This was necessary to protect the smaller Member States, like Malta, against the possible dominance of the larger Member States, like Germany, hence providing a safeguard for the interests of minorities that might

41 Kaczorowska-Ireland, note 40, p. 85.

42 Alford, note 38, p. 61.

43 Article 11(4) of the Treaty of the European Union (TEU). See Youri Devuyst, The European Union's Institutional Balance After the Treaty of Lisbon: Community Method and Democratic Deficit Reassessed, Georgetown Journal of International Law 39 (2008), p. 266.

44 Eid, note 15, p. 14.

45 Goebel, note 6, p. 84.

46 Article 17(3) TEU. Also see Goebel, note 6, p. 88.

47 Goebel, note 6, p. 91. 
be harmed by qualified majority voting in the Council of the European Union. ${ }^{48}$ As a general rule, the Council of the European Union acts through a qualified majority which is defined, with effect from 1 November 2014, as a vote of at least 55\% of the members of the Council, comprising at least fifteen of them and representing Member States comprising at least $65 \%$ of the population of the Union. ${ }^{49}$

In the context of the EAC, all partner states, whether big like Tanzania (the most populous country in the EAC as well as the is the largest in size, comprising $52 \%$ of the total area of the EAC region, hence bigger than all other partner states combined ${ }^{50}$ ) or small like Burundi (with $1.5 \%$ of the total surface area of the EAC region), have equal voting rights and weights, both in the Summit and the Council, and decisions are made by consensus. Only in the EALA, where decisions are made by a majority of votes, the interests of one country may be sidelined. This is regardless of the fact that members of the EALA do not vote along national lines as they are expected to act independently and without regard to any specific national interests. Be that as it may, the head of state of the supposedly sidelined member state is at liberty to block the decision by simply not assenting to the bill.

In the European Union, a legislation is enacted either through the ordinary procedure or special procedures, depending on the type of the law to be enacted. Article 294 of the Treaty on the Functioning of the European Union provides the ordinary legislative procedure which began by the Commission submitting a proposal to the European Parliament and the Council of the European Union. The ordinary procedure dominates the European Union legislative process as most legislation falls under this procedure. It is a co-decision procedure in which a joint adoption by the European Parliament and the Council of the European Union is required for a legislative proposal from the Commission. ${ }^{51}$ This power gives a veto power on the parliament on selected matters unlike under the previous cooperation procedure created by the Single European Act 1987 under which the Parliament could only amend the proposed law although the Council of European Union could ignore the proposal of the parliament through a unanimous vote. ${ }^{52}$

Additionally, legislative acts may also be adopted on the initiative of a group of Member States or of the European Parliament, on a recommendation from the European Central

48 Devuyst, note 43, p. 264.

49 Article 16(4) TEU. Other thresholds used in defining the qualified majority are provided for under Article 238 of the Treaty on the Functioning of the European Union (TFEU). Also see Folsom, note 39, pp. 49-50.

50 East African Community Secretariat, East African Community Facts and Figures - 2014, Arusha 2014, pp. 13, 16.

51 Article 289 TFEU.

52 Ralph H. Folsom, European Union Law in a Nutshell, Minnessota 2014, pp. 61-62; Folsom, note 39, pp. 41-43. On the previous methods used to adopt legislation in the European Union see Goebel, note 6, p. 61; Sven C. Oehme, An Overview of the European Union, its Legal Structure and its New Currency, New Jersey Lawyer 195 (1999), p. 9; Michael J. McCormick, A Primer on the European Union and Its Legal System, Army Lawyer 32 (2002); Eid, note 15, p. 15; Alford, note 38, p. 61 . 
Bank or at the request of the Court of Justice or the European Investment Bank only in the specific cases provided for by the Treaty on the Functioning of the European Union. ${ }^{53}$

\section{Lack of Coordination Between EALA and the Council}

Lack of a cordial and effective working relationship between the Council and the EALA on legislative issues inevitably hinders performances of the two organs, as they complement each other. With respect to the shared competency of initiating bills, this lack of coordination has created an emerging anarchy and the risk of populism in EAC politics. This is reflected in the ongoing duplication of efforts where the EALA is increasingly passing bills on matters under negotiation, opposed or agreed upon by the council, hence reopening the concluded negotiations as well as legislating on matters outside the scope of the Treaty.

To illustrate this, the following, randomly selected examples of bills passed by EALA without being supported or in clear defiance to the decisions of the Council, including bills which the council had to withdraw after realizing that the house was determined to amend the bill in a way contrary to its intention, are presented.

In 2004, four private member's bills were pending legislation in the Assembly, to wit, the East African Community Trade Negotiations Bill, the East African Community Budget Bill, the East African Immunities and Privileges Bill and the Inter-University Council for East Africa Bill. The Council thereafter decided that policy oriented bills, such as those that have implications on the partner states' sovereign interests and on the budgetary aspect of the Community, ought to be submitted to the Assembly by the Council under Article 14(3) (b) of the Treaty as opposed to being submitted as private member's bills under article 59 of the Treaty. The Council decided to assume responsibility for the four pending bills for consideration and submission to the Assembly. In May 2005, the Council also observed that some of the bills were similar to the protocols being developed. On 27 September 2005, Mr. John Koech, a Member of the Council, apparently on behalf of the Chairperson, made a Ministerial Statement from the floor of the Assembly, requesting the Speaker to defer consideration of the bills until policy input by the Council had been finalized and also givng an update to the Assembly on the current position of each Bill. On 7 December 2005, three members of EALA took the matter to the East African Court of Justice, seeking many determinations of the court, including whether the Council interfered with the functions of EALA and had powers to withdraw the impugned bills. The court decided in favour of the EALA members that, inter alia, the decision of the council was ineffective as a means to withdraw the bills and that the EALA is not bound by such a decision because a bill once introduced in the house become property of the EALA and might only be withdrawn at the 
request of the mover by leave of the house. The court added that the decisions of the Council have no place in areas of jurisdiction of the Assembly. ${ }^{54}$

In 2008, Hon. Dan Wandera Ogalo, a member of EALA from Uganda presented a bill entitled 'The East African Elections Bill'. The stated objective of this bill was to make provisions for the conduct of presidential and national assemblies' elections, to establish an EAC electoral commission, to provide for the registration and management of the Register, the demarcation of constituency boundaries, the appointment of election officers, election procedures and other incidental matters. The Council, through the Committee on Regional Affairs and Conflict Resolutions, opposed the bill on the basis that election matters are outside the scope of cooperation under the Treaty. It was also observed that in all partner states of the EAC, elections, especially for presidents and parliamentarians, are matters under their constitutions and therefore the EALA cannot enact legislation of such a kind. The bill was nevertheless admitted in the house but rejected on its second reading. However, EALA advised Hon. Ogalo to introduce another bill devoid of provisions on presidential elections, and the revised bill was passed in 2012.

In 2010, Hon. Safina Kwekwe Tsungu, a member of EALA from Kenya, submitted a bill entitled 'The East African Community Tourism and Wildlife Management Bill'. The stated objectives of the bill were to enact a law setting out the framework of cooperation in the tourism and wildlife management, to establish EAC Tourism and Wildlife Development Fund and to establish a commission that would be coordinating and supervising issues relating to tourism in the Community. Under the bill, the proposed commission would have powers to allocate hunting blocks and to set the necessary fees. The Council opposed the bill on the ground that there is no policy in place, regulating the tourism and wildlife sector and the policy was needed prior to enacting legislation. In the view of the Council, legislation has to build on pre-existing policies. The Council also opposed the bill because it was at same time negotiating a new protocol on this very matter. The EALA defied the Council's take on the matter and proceeded and proceeded to discuss and pass the bill.

In 2012, Hon. Frederic Ngenzebuhoro, a member of EALA from Burundi, introduced a bill on behalf of the EALA Committee on Legal, Rules and Privileges, entitled 'The East African Community Human and Peoples Rights Bill'. The bill intended to establish an EAC human and peoples' rights regime and give effect to the provisions of the Treaty on matters of human and peoples' rights. Coincidentally, this same bill was initially introduced to the Council by a Ugandan based civil society organization called "Kituo cha Katiba". The Council, upon receiving it, had immediately requested partner states to provide their comments on the proposed bill. It was while partner states were still commenting on the proposed bill, that Hon. introduced the same bill as a private members' bill to the EALA. The Council objected to the bill but the EALA debated and passed it on 25 April 2012.

54 Calist Andrew Mwatela, Lydia Wanyoto Mutende, Isaac Abraham Sepetu v. East African Community, Application No. 1 of 2005, EACJ. 
Incidentally, all the above bills as well as many other private members' bills passed by the EALA ${ }^{55}$, are not yet operational because not all Heads of State have assented them, presumably for not taking into account the views of the Council. Yet, time and resources have been spent in discussing the futile bills. Arguably, EAC funds paying the EALA members in such occasions are without value for money. This also raises the fundamental conundrum on the need for the legislative powers of EALA if its bills are not assented to. In any event, EAC interests are served best by such misunderstandings.

\section{Proposal to Amend the Treaty}

In 2012, the United Republic of Tanzania came up with a proposal to amend the Treaty, among others, on provisions relating to the initiation of bills in the EALA by streamlining the legislative process, taking into account challenges so far experienced with the initiation of bills by the EALA members. Tanzania also wanted more involvement of national parliaments in the EALA's legislative process, to increase the role of the Council as representative of the partner states and to ensure that sectoral ministers participate effectively through the Council in the legislative process. ${ }^{56}$

\section{The proposed amendments by Tanzania were as follows:}

Firstly, Article 14(3)(b) be amended by deleting the words "submit Bills to the Assembly" and replacing them with the words "and approve Bills together with the Assembly under the procedures provided for by Article 59 "A" of this Treaty". That means the Council would remain with the power to initiate bills and in addition have power to jointly approve, together with the presiding person in the house, all private members' bills introduced in the house. Currently private members' bills are subjected to the exclusive opinion of the person presiding over the meeting in the house.

55 Such as the East African Community Lake Victoria Basin Commission Bill 2007, the East African Community Elections Bill 2012, the Inter-University Council of East Africa (Amendment) Bill 2012, the East African Community HIV and AIDS Control and Prevention Bill 2012, and the East African Community Cross Border Legal Practice Bill, 2014.

56 Report of the Meeting of the High Level Task Force on the Amendment of the Treaty, Kigali, Rwanda, 24 October 2012, para. 3.1.2, pp. 6-7. 
Secondly, addition of a new Article 56 "A" with the title "Procedures for Passing Bills" which shall read as follows:

"Article 58 " $A$ "

Procedures for Passing Bills

a) Notwithstanding the provisions of Article $49(1)^{57}$ and Article $58^{58}$ of this Treaty, the procedures for passing Bills shall involve the Assembly and the Council;

b) Where no agreement is reached between the position of the Assembly and that of the Council on a Bill, the Assembly and the Council will appoint a Committee that will work on the matter and prepare an agreed position on the Bill;

c) Where there is no agreement reached by the Committee, the bill shall lapse;

d) The Assembly and the Council shall prepare Rules of procedures to operationalize this Article";

Arguably, this proposal introduces the elements of co-decision legislative mechanism as practiced in the European Parliament.

Thirdly, addition of a new Article 58"B" with the title "Roles of National Assemblies of the Partner States" and which shall read as follows

"Article 58 " $B$ "

Roles of National Assemblies

a) Once a Bill is introduced at the Assembly, the Clerk shall immediately transmit that Bill to the Clerk of the National Assemblies of Partner States;

b) The Clerks of the National Assemblies shall cause the Bill submitted under paragraph 1 of this Article to be discussed by the respective National Assembly;

c) The National Assemblies shall within the period of three months provide their comments concerning the Bill through the Clerk;

d) The Assembly and the Council shall consider comments from National Assemblies when passing Bills;

e) The Assembly shall prepare rules of procedures to govern the enforcement of this Article".

This third proposal is a modified version of the current article 65 of the Treaty on relations between the EALA and the national assemblies of the partner states. The objectives of article 65 are (a) to operationalize the policy of public participation in the EAC matters, (b) enable the Council to take into account the opinion of the general public through debates of the elected members of national assemblies on matters relating to the EAC, and (c) foster cooperation between the EALA and national assemblies. To achieve these objectives, Article 65 of the Treaty provides that:

57 Article 49(1) of the Treaty provides that: 'the Assembly shall be the legislative organ of the Community'.

58 Article 58 of the Treaty deals with voting in the Assembly. 
a) the Clerk of the Assembly shall as soon as practicable transmit to the Clerks of the National Assemblies copies of the records of all relevant debates of the meetings of the Assembly to be laid before the National Assemblies, by the respective Ministers responsible for East African Community affairs;

b) the Clerk of the Assembly shall as soon as practicable transmit to the Clerks of the National Assemblies copies of the Bills introduced into the Assembly and Acts of the Community to be laid before the National Assemblies for information;

c) the Clerks of the National Assemblies shall as soon as practicable transmit to the Clerk of the Assembly copies of the records of all relevant debates of the meetings of their National Assemblies other than those with respect to the matters laid before their National Assemblies in pursuance of the provisions of sub-paragraph (a) of this paragraph; and

d) the Clerk of the Assembly shall as soon as practicable transmit to the Secretary General copies of all the records of debate referred to in subparagraphs (a) and (b) of this paragraph for information to the Council.

Despite the above similarities between the proposed new Article 58"B" and the existing Article 65 of the Treaty, the proposed amendments do not seek to repeal or delete article 65 of the Treaty. It is submitted that the two articles should be harmonized and merged as one. Under Article 65(b) of the Treaty, bills from EALA are sent to the national assemblies for information purposes. Paragraph (c) of Article 65 requires reports of debates from national assemblies to be transmitted to the clerk of the EALA but no further action is required, therefore there is no way that the EALA as an institution is able to receive feedbacks from national assemblies. The proposed Article 58B requires action, by the national assemblies (to comment on bills tabled at EALA) and both the EALA and the Council (to take into considerations the comments provided for by national assemblies). This is the essence which needs to feature in the new, merged provisions.

\section{The Aftermath of the Proposal to Amend the Treaty}

Negotiations among the partner states on this proposal to amend the Treaty are still ongoing. This section is therefore going to present and discuss preliminary reactions or observations by EAC organs and other partner states on the proposal.

The EALA outrightly and strongly opposed the proposals on the grounds that they will affect the right of members to introduce private members' bills. ${ }^{59}$

The Republic of Uganda considered the proposals and observed the need to draw a clear distinction between Bills initiated by Council under Article 14(3)(b) of the Treaty and those initiated by elected members of EALA as provided for under Article 59. Drawing on

59 EALA Resolution passed on 13 September, 2012. See Official Report of the Proceedings of the East African Legislative Assembly of 13 September 2013, available at http:/www.eala.org/keydocuments/cat_view/45-key-documents/34-hansard/114-2012/129-september-2012.html (last accessed on 23 November 2013). 
experiences from the legislative process in the European Union, Uganda proposed that the proposal be restricted to private members' bills and national assemblies be kept out of the EAC legislative process.

The Republic of Kenya preliminarily observed that the proposal to amend the Treaty may contradict the intention of the contacting parties to provide for good governance, including the separation of powers in the institutional arrangements of the community. Kenya added that the concerns giving rise to Tanzania's proposal can be adequately addressed through the full operationalization of the existing relevant provisions of the Treaty, for example, Article 63 on assent to bills, Article 65 on relations between EALA and national assemblies, and Article 36 on seeking advisory opinion of the East African Court of Justice on any matters on implementation of the Treaty. Kenya also wanted further research to be undertaken by experts from all partner states on other regional economic blocs on how to best inform the proposed amendment. Coincidentally, this paper contributes to that objective.

The Republic of Rwanda also preliminarily observed that the co-legislation process of the European Union is not entirely ideal for the EAC as the context and the background differ. Furthermore, it was observed that (a) the proposed amendment does not take into account the different decision making mechanisms under the Treaty for the Council (on the basis of consensus) on the one hand, and the EALA (through voting) on the other hand, (b) the proposal on the Council assuming legislative power could hinder the smooth operation of the community and thereby violate the principle of separation of powers as reflected in the fundamental principle of good governance and in the Treaty's provisions on different organs' functions, (c) the provisions of Article 65 of the Treaty which provides an interface between national assemblies and the EALA were not taken into account; the issue of including national assemblies in the legislative process of the community is catered for under Article 49(2) ${ }^{60}$ and 65 respectively, (d) the provisions of Article 63 may be invoked where the Heads of State may withhold assent to the bill of the Assembly in the event that the views of the Council are not taken into account, and (e) proper collaboration and information sharing between the office of the Counsel to the Community and the EALA Clerk's office would help in solving the issue of bills that are passed by the EALA while they are being worked on by the Council.

The Republic of Burundi preliminarily observed that Tanzania's concerns could be addressed through improved coordination between national assemblies and the EALA as provide for under Article 65 of the Treaty, and that the Heads of State may withhold assent to any bill that may contradict the provisions of the Treaty.

It is submitted that all partner states are in agreement on the need to address the ongoing impasse between the Council and the EALA on the matter of private members' bills. There is however a lack of consensus on whether the said concerns may be addressed by

60 Article 49(2)(a) of the Treaty provides that the EALA shall liaise with the national assemblies of the partner states on matters relating to the Community. 
amending the Treaty or by simply operationalizing the existing, dormant provisions of the Treaty, particularly Articles 49(2) and 65 on relations between the EALA and national assemblies, as well as Article 63 on the withholding of assent by Heads of State on controversial bills. More importantly is a common fear of involving or giving a decisive role to the national assemblies in the regional legislative process, because this would be likely to impede the regional process due to specific national interests. Other fears lie in having a powerful Council with decisive legislative functions that might ultimately curtail the powers of the EALA, making it a subservient rubber stamp organ, and thereby hindering the smooth operation of the community by violating the principle of separation of powers enshrined in the fundamental principle of good governance of the EAC.

This paper does not seek to question the preliminary observations rightly made by the partner states in this issue. Irrespective of the outcomes of the proposed amendments, it is however crucial to note the following as far as the private members' bill is concerned, which is the focus of this paper.

\section{The Doctrine of Separation of Powers and the EAC}

It is submitted that the doctrine of separation of powers as expounded by the French lawyer Baron de La Brède et de Montesquieu in 1748 needs to be applied cautiously and in this context it cannot be invoked to grant unlimited powers to the EALA as far as initiation of bills is concerned. Any attempt to hold fast to this rule would be tantamount to upholding sectional interests and concerns by defeating the original ideals of the concept itself. The principle is also not without inadequacies and controversies. Eoin Carolan rightly argues that the simple Montesquian doctrine of separation of powers is not capable of effectively acting as a principle of institutional organization because it is too vague, descriptively inadequate and internally incoherent. ${ }^{61}$

The principle therefore needs to be interpreted and applied contextually to determine its specificities in the light of its foundational objectives. And, in a modern democracy which the EAC partner states are striving to promote, the doctrine must also strive to defend the public interest rather than sectional interests. In the context of law-making, the foundational objective of the doctrine of the separation of powers is to ensure that law is made in the objective and precise public interests. ${ }^{62}$ The fundamental conundrum then is whether the private members' bills of EALA enacted in clear violation or contrary to the guidance of the Council, and occasionally outside the scope of cooperation under the Treaty, are objective, precise and in the public interest of the EAC as enshrined in the Treaty. Arguably, there is no public interest served by futile bills that, at best, simply justify countless sessions of the EALA meetings at the expense of the EAC coffers.

61 Eoin Carolan, The New Separation of Powers: A Theory for the Modern State, Oxford 2009, p. 253.

62 Carolan, note 61, pp. 27-28. 
The other reason for a cautious application of the doctrine of separation of powers stems from the doctrine's intention which was not to promote efficiency, but to preclude autocracy and the arbitrary exercise of power. As Justice Louis Brandeis says, 'the purpose was not to avoid friction, but, by means of the inevitable friction incident to the distribution of the governmental powers among three departments, to save the people from autocracy'. ${ }^{63}$ Accordingly, applying the principle of separation of powers cannot solve the friction between the EALA and the Council. It is the autocracy that needs to be prevented and the public interest to be promoted and not protection of sectional interest of EALA to freely initiate bills through private motions.

The doctrine of separation of powers entails checks and balances among the organs of state and does not seek to vest absolute powers within one organ at the expense another. Furthermore, the relevance of the doctrine of separation of powers in an integration scheme is questionable, and more so in intergovernmental organizations. Instead, the doctrine of competency or the principle of specific conferment of power is often applied such that every organ must only act within its sphere of given competence as per the founding document, in this case the Treaty. Competencies flow from the legally circumscribed authority over specific domains of action as opposed to sovereignty, which is essentially the power to allocate or retain competencies by a governing entity. ${ }^{64}$ The organs of an integration project do not possess inherent powers. What is necessary is to achieve the set objective of integration. To insist on the principle of separation of powers at the expense of the attainment of the objectives of the Treaty is tantamount to a disservice to the community.

On a comparative note, the existing complex hybrid institutional system of the European Union and the fact that European Union is neither a state nor a federation nor a traditional intergovernmental organization make the doctrine of separation of powers inapplicable and inadequate to describe power relationships among the European Union institutions and organs. ${ }^{65}$ Instead, the concept of institutional balance of power among the institutions has been used to guide the evolution and the efficiency of the European Union through a specific conferment of powers. As alluded to above, the governance of the European Union has been, in simplified form, described as a structure where the European Commission proposes, the Parliament advises, the Council of the European Union decides, and the Court of Justice rules. Already, the 'predominance of the Council of the European Union has become increasingly embarrassing and intolerable'. ${ }^{66}$ It has also been argued that the principle of specific conferment of power is applied in the European Union to ensure that the slow but ever-increasing reduction of the member states' sovereignty can be controlled. ${ }^{67}$

63 Roscoe Pound, The Development of Constitutional Guarantees of Liberty, New Haven 1957, p. 94.

64 Douglas R. Holmes, Integral Europe: Fast-Capitalism, Multiculturalism, Neofascism, Princeton and Oxford 2000, p. 211.

65 Kaczorowska-Ireland, note 40, pp. 63-64.

66 Folsom, note 39, p. 25.

67 Oehme, note 52, p. 9. 
The current institutional framework of the European Union is based on the French social modernism designed by Étienne Clémentel and Jean Monnet as a post-World War II reconstruction plan in 1951 . The rationale behind the plan was to undermine ideological differences and promote participation by adjusting production to requirements and by creating a system where everyone could see where his own efforts fitted in with everyone elses'. Accordingly, the European Commission and the European Council (counterparts to the Planning Commission and the Planning Council under the French Plan) became the dominant executive and legislative institutions respectively of the European Community and the European Parliament was vested with a minor role, remaining essentially a consultative body that conferred a modest democratic legitimacy on the project's actions. ${ }^{68}$

\section{Effecting Consultations Between National Assemblies and the EALA}

It has been suggested that the concerns giving rise to Tanzania's proposal can be adequately addressed through the full operationalization of the existing relevant provisions of the Treaty on the relationship between the EALA and national assemblies (articles 49(2) and 65) as well as articles 36 and 14(4), which enable the Council to seek advisory opinions from the East African Court of Justice on any matter).

It is submitted that such consultations would be helpful if the root of the problem was the lack of information or ignorance on the part of the EALA as to the opinions of the general public (which could be brought to its attention through debates in national assemblies) and partner states (stated in the Council). In the current scenario, the EALA is knowledgeable and well informed of the Council's positions on each of these futile legislations. As alluded to above, some bills are being passed on matters under negotiation or already opposed or agreed upon by the council. The EALA simply opts to stick to its guns, as it is supposed to act independently without being bound by any instructions or orders from any person or authority, including the Council. ${ }^{69}$ Article 65 of the Treaty is primarily a policy tool to achieve a popular participation in the EAC matters and not a legislative rule. It is an optional policy and the EALA is not bound by the outcomes of the consultations in exercising its functions.

As explained in the premises, operationalization of these above articles will not entirely solve the problem. Private members' bills need to be better regulated in the interests of the community. The EAC integration is suffering from the awkward and deadlocked relationship between the Council and the EALA as far as legislative process is concerned. The situation needs to get better soon before it gets worse.

68 Holmes, note 64, pp. 46-47.

69 Rule 3(1) of the East African Legislative Assembly Rules of Procedure. 


\section{Power of Assent by the Heads of State}

The often-suggested way to deal with EALA bills passed contrary to the views of the Council is to invoke the provisions of Article 63: withholding the head of state's assent. The essence of assent is that heads of state are the equal counterparts of the EALA, who must agree with a bill passed by the house before it becomes law. Indeed, as alluded to above, several private members' bills passed by the EALA are lined up, awaiting assent.

It is submitted that the power of assent can block the operationalization of a bill but cannot save the resources used in passing the said bill and mediate the working relationship between the EALA and the Council. Furthermore, the ancient prerogative power of the head of state to discretionarily assent to all bills is fading away in the emerging democratic dispensations. Already in some jurisdictions, like under the Irish Constitution, the president does not have discretion as to whether to provide the signature or not, after a bill has been passed by the national assembly. ${ }^{70}$ This is perhaps the future of the EAC. In any case, it is prudent for the bill to be forwarded to the head of state when there is a strong convention and assurance that the president will always give assent. In the emerging community and democracies like those of EAC partner states, for instance, the denial of assent by only one or more of Heads of State may attract unnecessary political and public squabbles. Presidency is the most demanding, sensitive and highly politicized institution and should therefore be relieved from all possible trivial matters that can easily and adequately be fixed in alternative fora. ${ }^{71}$

\section{Conclusion}

All partner states see the need to address the ongoing impasse between the Council and the EALA on private members' bills where bills on matters under negotiation, opposed or already agreed upon by the Council are being passed by the EALA. The cordial and effective working relationship between the Council and the EALA is paramount for their better performances in the interest of the EAC. Moreover, tension will affect the timely attainment of a prosperous, competitive, secure, stable and politically united EAC. There is however a lack of consensus as to whether the concerns on private members' bills are better handled by amendments to the Treaty or operationalization of the existing dormant provisions of the Treaty, particularly Articles 49(2) and 65 on relations between the EALA and national assemblies as well as Article 63 on denial of assent by heads of state to the controversial bills. Coincidentally, as far as the legislative function is concerned, the EALA stands out in sharp, admirable contrast to all other regional parliamentary bodies in Africa, as all other regional parliamentary bodies are without legislative functions. In this context, the only

70 Bruce V. Harris, The Irish President, the New Zealand Governor-General and the Head of State in a Future New Zealand Republic, NZ Law Review 605 (2009), p. 641.

71 This is the essence of the subsidiarity principle under Article 7(1)(d) of the Treaty. 
yardstick to measure EALA is the European Parliament, despite various differences between the two.

It is submitted that the proposed amendment to the Treaty empowering the Council to approve private members' bills does neither delete nor destroy the stature, validity, legitimacy or effectiveness of the private members' bills or the EALA. Enabling the Council to, jointly with the EALA, approve private motions is a sound move and should not be seen as giving the Council tyrannical decisive legislative functions at the expense of EALA. In order to ensure that the Council does not arbitrarily frustrate the EALA by not approving the private members' bills referred to it, the East African Court of Justice should be empowered to review the decisions of the Council in the light of the Treaty. Furthermore, the Treaty should clearly state that any failure of the Council to respond within a certain, prescribed time to the request for approval, should be deemed as constituting the approval to a particular private member's bill.

Additionally, as discussed above from the hindsight experience of the European Union, empowering the Council to approve the private member's bills will likely promote and ensure smooth coordination between the two organs of the community, and will not violate the foundational ideals of the principle of separation of powers enshrined in the Treaty, to wit, avoid autocracy. It is also an inconvenient truth that the EALA does not enjoy the presumptive legitimacy of a representative democracy in the strict sense because its members are not popularly elected. Morevoer, since the EAC is not a state but a state-centric, intergovernmental organization, the doctrine of separation of powers is of only limited use. The doctrine was not primarily invented to promote efficiency, which is central in regional integration projects. Instead, the concept of institutional balance of power among the EAC institutions through a specific conferment of powers is more ideal for the evolution and the efficiency of the EAC.

As argued above, the current tension between the EALA and the Council can only be resolved through a reform of the Treaty. The root cause of the impasse lies in the structural architecture of the Treaty and therefore merely activating the dormant provisions in the Treaty regarding the relationship between the EALA and the national assemblies or the Council will not solve the current impasse because the said dormant provisions were meant to be a tool for public participation and not a necessary legislative step. Furthermore, the denial of assent by heads of state on the controversial bills will in the long run create more problems than it will solve. At best, the power of assent can prevent the operationalization of a bill, but it cannot save resources used in passing the said bill or prevent the squabbles associated with such a denial of assent. 